\title{
Annexin A2-Mediated Internalization of Staphylococcus aureus into Bovine Mammary Epithelial Cells Requires Its Interaction with Clumping Factor B
}

\author{
Yi-Tian Ying ${ }^{1,2,3}$, Wei-Jia Ren ${ }^{1,2,3}$, Xun Tan ${ }^{1,2,3, *}$, Jing Yang ${ }^{1,2,3}$, Rui Liu ${ }^{1}$ and Ai-Fang Du ${ }^{1,2,3}$ \\ 1 Department of Veterinary Medicine, Zhejiang University, Yuhangtang Road 866, Hangzhou 310058, China; \\ yingyitian@zju.edu.cn (Y.-T.Y.); 22017103@zju.edu.cn (W.-J.R.); 21917098@zju.edu.cn (J.Y.); \\ 3170100083@zju.edu.cn (R.L.); afdu@zju.edu.cn (A.-F.D.) \\ 2 Veterinary Medical Center, Zhejiang University, Yuhangtang Road 866, Hangzhou 310058, China \\ 3 Institute of Preventive Veterinary Sciences, Zhejiang University, Yuhangtang Road 866, \\ Hangzhou 310058, China \\ * Correspondence: tanxun@zju.edu.cn
}

\section{check for}

updates

Citation: Ying, Y.-T.; Ren, W.-J.; Tan, X.; Yang, J.; Liu, R.; Du, A.-F. Annexin A2-Mediated Internalization of Staphylococcus aureus into Bovine Mammary Epithelial Cells Requires Its Interaction with Clumping Factor B. Microorganisms 2021, 9, 2090. https: / /doi.org/10.3390/ microorganisms 9102090

Academic Editors: Chao-Nan Lin and Peck Toung Ooi

Received: 11 September 2021

Accepted: 1 October 2021

Published: 3 October 2021

Publisher's Note: MDPI stays neutral with regard to jurisdictional claims in published maps and institutional affiliations.

Copyright: (c) 2021 by the authors. Licensee MDPI, Basel, Switzerland. This article is an open access article distributed under the terms and conditions of the Creative Commons Attribution (CC BY) license (https:/ / creativecommons.org/licenses/by/ $4.0 /)$.
Abstract: Background: Staphylococcus aureus is a leading cause of contagious mastitis in dairy cattle. Internalization of $S$. aureus by bovine mammary gland epithelial cells is thought to be responsible for persistent and chronic intramammary infection, but the underlying mechanisms are not fully understood. Methods: In the present study, we evaluated the role of Annexin A2 (AnxA2), a membrane-binding protein, in S. aureus invasion into bovine mammary epithelial cell line (MAC-T). In vitro binding assays were performed to co-immunoprecipitate the binding proteins of AnxA2 in the lysates of $S$. aureus. Results: AnxA2 mediated the internalization but not adherence of $S$. aureus. Engagement of AnxA2 stimulated an integrin-linked protein kinase (ILK)/p38 MAPK cascade to induce S. aureus invasion. One of the AnxA2-precipitated proteins was identified as S. aureus clumping factor B (ClfB) through use of mass spectrometry. Direct binding of ClfB to AnxA2 was further confirmed by using a pull-down assay. Pre-incubation with recombinant ClfB protein enhanced S. aureus internalization, an effect that was specially blocked by anti-AnxA2 antibody. Conclusion: Our results demonstrate that binding of $\mathrm{ClfB}$ to AnxA2 has a function in promoting S. aureus internalization. Targeting the interaction of $\mathrm{ClfB}$ and AnxA2 may confer protection against S. aureus mastitis.

Keywords: Staphylococcus aureus; annexin A2; clumping factor B; mammary epithelial cells

\section{Introduction}

Staphylococcus aureus is a major cause of infections in both human beings and a large number of animal species, including dairy cows. In humans, S. aureus causes a wide spectrum of diseases that range from cutaneous abscesses to life-threatening sepsis, accounting for considerable morbidity and mortality worldwide [1]. S. aureus is also a leading cause of contagious mastitis (infection of the mammary gland) in cattle and strikes the greatest challenge in the dairy industry [2-5]. S. aureus mastitis is extremely difficult to eradicate from herds, causing huge financial losses due to decreased milk yield, lowered milk quality, and premature culling of infected animals [2,6,7]. Furthermore, dairy products contaminated with toxins and enzymes produced by $S$. aureus can lead to food-borne diseases as it passes along the food chain [8,9]. In addition, cows have been recognized as the main animal reservoir for the emergent $S$. aureus clones that are epidemic in human populations $[10,11]$.

As a facultative intracellular pathogen, S. aureus can be internalized by, and survive within, many types of non-phagocytic cells, such as human endothelial cells [12], epithelial cells [13,14], and keratinocyte [15]. Internalization of $S$. aureus by bovine mammary gland epithelial cells has also been demonstrated [16-18]. The internalization protects the bacteria from host immune defenses as well as antimicrobial killing, leading to the development 
of persistent or chronic infections [19-21]. Invasion of non-professional phagocytes by $S$. aureus is mediated by a number of adhesins on the bacterial surface, which interact either directly or indirectly with extracellular matrix (ECM) or specific surface receptors on the host cells [22]. MSCRAMMs (microbial surface component recognizing adhesive matrix molecules) are the largest family of adhesins, which target the host's extracellular matrix proteins, such as collagen, fibrinogen, fibronectin (Fn), or laminin, for adhesion [23-25]. The interaction between Fn binding proteins (FnBPs, which are MSCRAMMs) on the bacteria and $\alpha 5 \beta 1$ integrin on the host cells via an Fn bridge has been considered as the most common pathway for the adhesion and internalization of S. aureus [26]. Bacterial engagement of the integrin $\alpha 5 \beta 1$ triggers intracellular signaling cascades and subsequent rearrangement of the host cell cytoskeleton to guide staphylococcal endocytosis [27]. Nevertheless, other studies have provided evidence for an FnBP-independent engulfment of S. aureus $[16,28]$.

There is increasing evidence showing that Annexin A2 (AnxA2), a member of the annexin family of $\mathrm{Ca}^{2+}$-regulated phospholipid-binding and membrane-binding proteins, functions as a host receptor for bacterial adhesion and/ or invasion into non-phagocytic cells [29-31]. AnxA2 is expressed in the majority of cells and tissues and binds to numerous ligands, and is associated with multiple membrane related functions, including exocytosis and endocytosis, membrane domain organization, actin remodeling, and signal transduction [32]. More recently, an interaction between S. aureus clumping factor A (ClfA) and AnxA2 on bovine mammary cells has been identified in an in vitro protein binding assay [33]. However, the intracellular events initiated by bacterial engagement of AnxA2 are poorly understood. In addition, further evidence regarding the interaction of ClfA and AnxA2 is lacking.

In the present study, we evaluated the engagement of AnxA2 in bacterial internalization into bovine mammary epithelial cells by using a clinical isolate of S. aureus (Clin-SA). In some experiments, a reference strain ATCC 25923 was used to validate the findings from Clin-SA. We demonstrate that bacterial engagement of AnxA2 regulates F-actin rearrangement via integrin-linked protein kinase (ILK)/p38 MAPK pathway. We have also examined Clin-SA lysates for the presence of AnxA2-binding proteins. Surprisingly, we identify ClfB but not ClfA as a component of the AnxA2-binding complex. Subsequently, we show that pretreatment of a recombinant $\mathrm{ClfB}$ protein enhances subsequent bacterial internalization, an effect that could be blocked by anti-AnxA2. Taken together, this work identifies ClfB as a novel AnxA2-binding protein that regulates the invasion of $S$. aureus.

\section{Materials and Methods}

\subsection{Bacterial Strains and Culture Conditions}

S. aureus strain (Clin-SA) was isolated from mastitic milk samples. The identity of the bacteria strain was confirmed by means of culture, Gram staining, and 16S rRNA gene sequencing. S. aureus strain ATCC 25923 was a gift from H-Q. Li, Lanzhou Institute of Animal Husbandry and Veterinary Pharmaceutical, Chinese Academy of Agricultural Sciences. Prior to use, bacteria were grown at $37^{\circ} \mathrm{C}$ in brain heart infusion (BHI) with constant aeration $(220 \mathrm{rpm})$ to establish the early exponential phase cultures (OD600 $=0.8-1.0)$. $S$. aureus colony-forming units (CFU) were quantified on Lysogeny broth (LB) plates incubated overnight at $37^{\circ} \mathrm{C}$. In some experiments, staphylococci were labeled with FITC prior to infection [19]. Labeled bacteria were extensively washed with Dulbecco's phosphatebuffered saline (DPBS) prior to use.

\subsection{Invasion and Adherence Assays}

Bovine mammary epithelial cell line MAC-T (generously provided from Zhu Y., Chinese Agricultural University, Beijing) and porcine intestinal epithelial cell line IPEC-J2 were cultured in Dulbecco's Modified Eagle Medium (DMEM) supplemented with 10\% fetal bovine serum (FBS) at $37{ }^{\circ} \mathrm{C}, 5 \% \mathrm{CO}_{2}$. Cells were subcultured every 2 days. Bacterial invasion was evaluated with gentamicin protection assay [13]. In brief, MAC-T cells (unless 
stated otherwise) were seeded in 24-well tissue culture plates at $5 \times 10^{4}$ cells/well and grown in growth medium. For confocal microscopy, glass coverslips were placed into the wells. After $24 \mathrm{~h}$ of incubation, the culture medium was aspirated and replaced with invasion medium (growth medium without FBS) and the cells infected with Clin-SA or ATCC 25923 at indicated multiplicity of infection (MOI) for $1 \mathrm{~h}$. After washing with DPBS, invasion medium containing $0.2 \mu \mathrm{g} / \mathrm{mL}$ gentamicin was added into each well to kill all remaining extracellular $S$. aureus. Thereafter, the cells were washed twice with DPBS and intracellular bacteria released by incubation in $0.25 \%$ Triton X-100 for $25 \mathrm{~min}$. Samples were serially diluted in DPBS and plated on LB agar plates for determination of the recovered colony forming units (CFU). An adherence assay was performed as described for the gentamicin protection assay, except that no antibiotic was added to the MAC-T monolayers before cell lysing. It is believed that the contribution of internalized bacteria to adherence is very low [34].

\subsection{Cytochalasin D Assay}

Cytochalasin D (Cyt D) assay procedure was carried out as described previously [13]. Briefly, MAC-T cells were preincubated with actin-depolymerization agent Cyt D (SigmaAldrich, Saint Louis, MO, USA) at $50 \mu \mathrm{g} / \mathrm{mL} 2 \mathrm{~h}$ prior to inoculation with bacteria to allow the disruption of the actin filaments and the inhibition of actin polymerization. After incubation with bacteria for $1 \mathrm{~h}$ at $37^{\circ} \mathrm{C}$, a gentamicin protection assay was performed as described above.

\subsection{Transmission Electron Microscopy}

MAC-T cultures were grown in 6-well plates and infected with Clin-SA as described above. Following washing in the DPBS, the cells were fixed in $2.5 \%$ glutaraldehyde, postfixed in $1 \%$ OsO4, and processed for transmission electron microscopy (JEM-1200, JEOL, Japan) as previously described [18].

\subsection{Confocal Microscopy}

MAC-T cells were fixed with $4 \%$ paraformaldehyde for $30 \mathrm{~min}$, followed by permeabilization in $0.25 \%$ Triton X-100 for $15 \mathrm{~min}$. The cells were then incubated with $50 \mu \mathrm{M}$ TRITC-labelled phalloidin (Sigma-Aldrich, Saint Louis, MO, USA) in invasion medium for $30 \mathrm{~min}$ at room temperature to visualize the actin cytoskeleton. The samples were viewed with a confocal laser scanning microscope (Olympus IX81-FV1000).

\subsection{Recombinant ClfB Protein}

To generate recombinant ClfB protein, a full-length $C l f B$ DNA fragment was amplified by PCR by using ATCC 25923 strain chromosomal DNA as template and subcloned into expressing vector pGEX-4T-1 (Clontech, Mountain View, CA, USA). PCR primers were as follows: forward 5'-GGT ACC ACA TCA GTA ATA GTA GG-3', reverse 5'-TCT TTA TGA TCT TGC TTG CGT T- $3^{\prime}$. The recombinant GST-tag ClfB protein was produced in BL21 bacteria strain, purified by using BeyoGold ${ }^{\mathrm{TM}}$ GST-tag Purification Resin (Beyotime Biotech, Nanjing, China) according to the manufacturer's protocol, and dialyzed at $4{ }^{\circ} \mathrm{C}$ by using a dialysis bag with molecular weight cut-off of 8-14 kDa (Sigma-Aldrich, Saint Louis, MO, USA). The dialyzed protein was stored at $-80^{\circ} \mathrm{C}$ prior to use.

\subsection{Gene Silencing by siRNAs}

Small interfering RNAs (siRNAs) targeting bovine $A n x A 2$ and ILK or negative control siRNA (NC-siRNA) were purchased from GenePharma (Shanghai, China). Cells were transfected with siRNAs using Lipofectamine 2000 (Invitrogen, Carlsbad, CA, USA) according to the manufacturer's instructions. The siRNAs designed to target the coding regions of AnxA2 and ILK were as follows: AnxA2, 5'-GCG GGA UGC UCU GAA CAU UTT- $3^{\prime}$ (sense), 5'-AAU GUU CAG AGC AUC CCG CTT-3' (antisense); ILK, 5'-GCU ACA UGA AGG CAC CAA UTT-3' (sense), 5'-AUU GGU GCC UUC AUG UAG CTT-3' (antisense). 
Negative control siRNA sequences were 5'-UUC UCC GAA CGU GUC ACG UTT-3' (sense) and 5'-ACG UGA CAC GUU CGG AGA ATT-3' (antisense). The final concentration of the siRNAs was $20 \mathrm{nmol} / \mathrm{L}$. Knockdown efficiencies were determined by qPCR and Western blot after 48 or $72 \mathrm{~h}$ of transfection.

\subsection{Overexpression of $A n x A 2$ in $M A C-T$}

Expression plasmid coding the full length of the open reading frame (ORF) of $A n x A 2$ (Gene ID: 282689) was constructed by using pEGFP-C3 vector (Clontech, Mountain View, CA, USA). A Kozak sequence (GCCACC) was introduced immediately after the ATG to optimize the expression of the fusion protein. Cells were seeded at $2 \times 10^{5}$ cells / well in 6-well cell culture plates and cultured overnight prior to transfection. Plasmid transfection was carried out using Lipofectamine ${ }^{\circledR} 2000$ reagent (Invitrogen, Carlsbad, CA, USA) according to the manufacture's procedure. Cells transfected with empty plasmid were served as controls. After $48 \mathrm{~h}$ of transfection, the cells were subjected to bacterial infection at indicated MOI for $1 \mathrm{~h}$.

\subsection{Western Blotting Analysis}

Total cell lysates and immunoprecipitates were separated by sodium dodecyl sulfate (SDS)-12\% polyacrylamide gel electrophoresis (PAGE) and blotted onto to polyvinylidene difluoride (PVDF) membranes (Millipore, USA). The following primary antibodies were used for immunodetection: AnxA2, ILK, and p-p38 (Santa Cruz Biotechnology) at 1:1000to 1:2000-fold dilutions. After incubation overnight at $4{ }^{\circ} \mathrm{C}$, blots were exposed to the appropriate horseradish peroxidase (HRP)-conjugated secondary antibody (Huabio, Hangzhou, China). Immunoreactive bands were visualized by electrochemiluminescent (ECL) (FDbio Science, Hangzhou, China). $\beta$-actin served as loading controls.

\subsection{Immunoprecipitation and MS Analysis}

Identification of the binding partners of host AnxA2 in the Clin-SA was carried out by co-immunoprecipitation (co-IP) coupled to mass spectrometry (MS) analysis. Bacteria were harvested at OD600 of $0.6-0.8$ by centrifugation at $5000 \times g$ at room temperature for $5 \mathrm{~min}$. The pellet was washed twice with DPBS, resuspended in a lysis buffer $(50 \mathrm{mM}$ Tris- $\mathrm{HCl}$ at pH8.9, $250 \mathrm{mM} \mathrm{NaCl}, 1 \mathrm{mM}$ PMSF and $100 \mathrm{mg} / \mathrm{mL}$ lysozyme) at $1 \mathrm{~g}$ wet pellet/10 mL, and sonicated with a 150 Watt ultrasonic processor at $60 \%$ amplitude with pulse durations of $2 \mathrm{~s}$ on and $4 \mathrm{~s}$ off. The samples were centrifuged at $14,000 \times \mathrm{g}$ at $4{ }^{\circ} \mathrm{C}$ for $30 \mathrm{~min}$ to remove the cellular debris and aggregate. The supernatant was used for subsequent binding analyses. Total protein concentrations were quantified by a BCA kit according to the manufacturer's instruction (Meilunbio, Dalian, China). MAC-T cells were lysed with 1\% Triton X-100 containing protease inhibitor cocktail on ice for $1 \mathrm{~h}$. Thereafter, $400 \mu \mathrm{g}$ protein from MAC-T cells was mixed with $500 \mu \mathrm{g}$ protein from bacteria and the mixture was incubated overnight at $4{ }^{\circ} \mathrm{C}$. The protein A/G magnetic beads (Bimake, Shanghai, China) conjugated with antiAnxA2 mAb was added into the mixture to capture the AnxA2-binding proteins. The immunoprecipitates were then analyzed by SDS-PAGE, using $12 \%$ polyacrylamide gel, and detected by silver staining. The gel bands were excised and in-gel digested with $12.5 \mathrm{ng} / \mu \mathrm{L}$ trypsin in $25 \mathrm{mM} \mathrm{NH} \mathrm{HCO}_{3}$. LC-MS/MS analysis was performed on a $\mathrm{Q}$ Exactive mass spectrometer (Thermo Scientific, Shanghai, China) coupled to Easy nLC (Proxeon Biosystems, Odense, Denmark). The mass spectrometer was operated in positive ion mode. MS data were acquired using a data-dependent top 10 method, dynamically choosing the most abundant precursor ions from the survey scan (300-1800 m/z) for higher energy collisional dissociation (HCD) fragmentation. Full MS AGC target was 3E6 with a maximum injection time of $10 \mathrm{~ms}$. Dynamic exclusion duration was $40.0 \mathrm{~s}$. Survey scans were acquired at a resolution of 70,000 at $\mathrm{m} / z 200$ and resolution for HCD spectra was set to 17,500 at $\mathrm{m} / \mathrm{z} 200$, and isolation width was $2 \mathrm{~m} / \mathrm{z}$. Normalized collision energy was $30 \mathrm{eV}$ and the underfill ratio, which specifies the minimum percentage of the target value likely to be reached at maximum fill time, was defined as $0.1 \%$. The instrument was run with 
peptide recognition mode enabled. The MS/MS spectra were searched using MASCOT engine (Matrix Science, London, UK; version 2.4) against the UniProtKB S. aureus database (105867 total entries, downloaded 14 June 2019). Search parameters were set as follows: enzyme, Trypsin; peptide mass tolerance, 20 ppm; fragment ion mass tolerance, $0.1 \mathrm{Da}$; maximum missed cleavages allowed, 2; fixed modification, carbamidomethyl (C); variable modification, oxidation (M); and ion score $>20$.

\subsection{Pull-Down Assay}

An in vitro pull down assay was performed using BeyoGold ${ }^{\text {TM }}$ GST-tag Purification Resin (Beyotime Biotech, Nanjing, China) according to the manufacturer's instructions. In brief, GST or GST-ClfB was incubated overnight with MAC-T cell lysates and Sepharose CL-6B beads in NP-40 buffer at $4{ }^{\circ} \mathrm{C}$. After washing in NP-40 buffer 3 times, the beads were suspended in SDS-PAGE loading buffer and boiled for $5 \mathrm{~min}$. The protein complex was separated by SDS-PAGE and then analyzed by Western blot.

\subsection{Statistical Analysis}

Data are presented as mean \pm standard deviation (s.d.). Statistical analysis was performed with the SPSS software v.22. The differences between two groups were analyzed using Student's $t$-test, while one-way ANOVA followed by LSD correction was applied to compare more than two groups. Differences were considered significant for $p<0.05$.

\section{Results}

\subsection{AnxA2 Is Required for the Internalization of S. aureus by MAC-T Cells}

S. aureus was able to invade into bovine mammary epithelial cells (Figure 1A) [18]. To clarify whether AnxA2 has a functional role in the adherence or invasion of S. aureus, or both, we blocked the membrane function of AnxA2 by incubating MAC-T cells with an antiAnxA2 antibody. Interestingly, blocking AnxA2 function at the cell surface had no effect on $S$. aureus adherence, but led to a significant decrease in the intracellular bacteria protected from gentamicin killing (Figure 1B). Further studies were conducted to evaluate the role of host AnxA2 on S. aureus adherence and internalization by using AnxA2-depleted MAC-T cells. Western blotting of whole extracts from cells treated with siRNA targeting AnxA2 for $72 \mathrm{~h}$ revealed marked depletion of AnxA2 (Figure 1C). While AnxA2 knockdown resulted in a significant decrease in $S$. aureus uptake, we did not observe a significant change in S. aureus adherence (Figure 1C). To further confirm the role of AnxA2, we performed overexpression of AnxA2 in MAC-T cells (Figure 1D). AnxA2 overexpression significantly enhanced bacterial invasion without altering the number of bacteria attached to MAC-T cells (Figure 1D). Taken together, our observations suggest that AnxA2 is necessary for staphylococci internalization but not adherence.

\subsection{AnxA2 Contributes to S. aureus-Induced Actin Cytoskeleton Reorganization}

Actin cytoskeleton is crucial for $S$. aureus uptake by MAC-T, as Cyt D, which interferes with F-actin polymerization (Figure 2A), severely blocks Clin-SA internalization into MAC-T (Figure 2A,B) [27,35]. Similarly, Cyt D treatment led to a significant reduction in the uptake of a reference strain of $S$. aureus, ATCC 25923, by MAC-T cells (Figure 2C), suggesting the cytoskeleton-dependent invasion of $S$. aureus is not strain-specific. Since AnxA2 functions in the dynamic reorganization of F-actin cytoskeleton [36], we next used AnxA2-deficient MAC-T cells to evaluate the role of AnxA2 in S. aureus-induced cytoskeleton reorganization. As expected, AnxA2 depletion led to a major change in the organization of actin cytoskeleton upon S. aureus infection (Figure 2D). This result, along with the finding that loss of AnxA2 caused a significant reduction in bacterial invasion (see above, Figure 1C), indicates that AnxA2 plays a role in S. aureus-induced reorganization of actin cytoskeleton. 
A

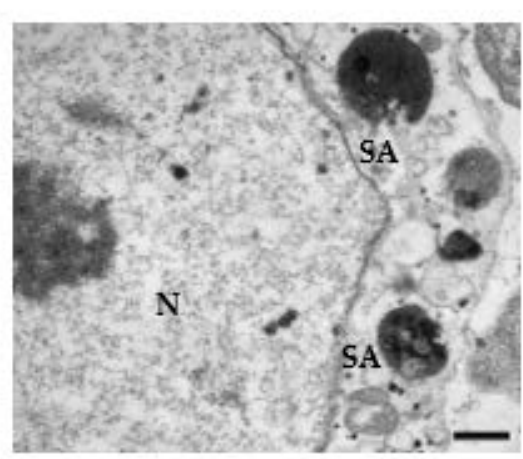

B
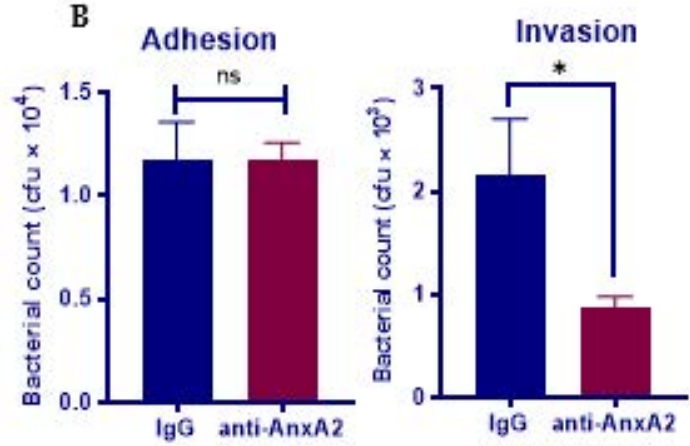
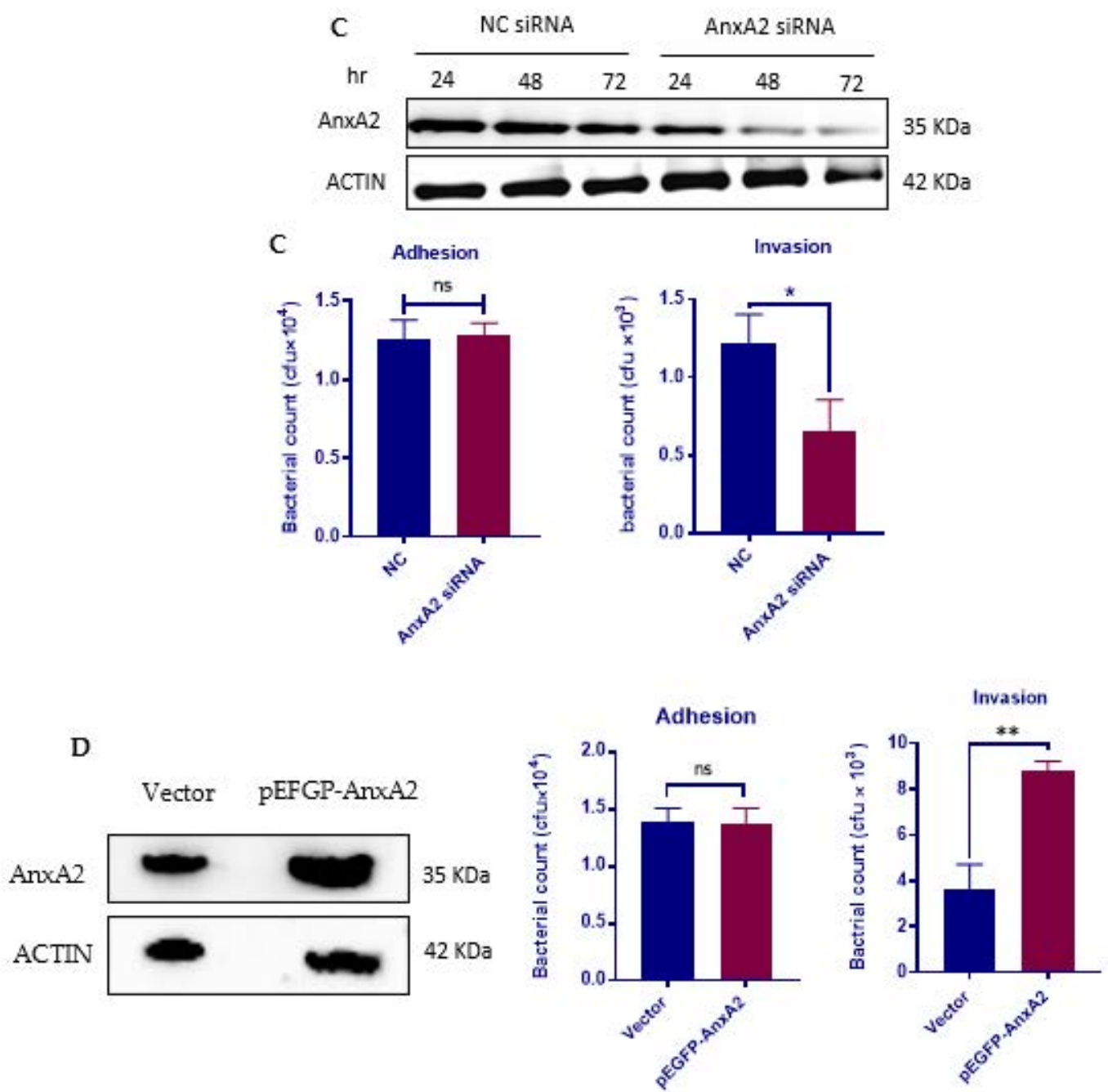

Figure 1. AnxA2 mediates the invasion of S. aureus. (A) Transmission electron micrograph showing internalization of a clinical isolate of S. aureus (Clin-SA) into MAC-T. Two engulfed bacteria (boxed) are displayed at high magnification. Photograph represents a $1 \mathrm{~h}$ co-culture of cell monolayer with Clin-SA at a MOI of 50. N: nucleus; C: cytoplasm. Scale bar: $500 \mathrm{~nm}$. (B-D) Effect of AnxA2 on S. aureus adhesion to and uptake by MAC-T cells. MAC-T cells were pre-incubated with anti-AnxA2 antibody $(17.5 \mu \mathrm{g} / \mathrm{mL})$ or human $\operatorname{IgG}(17.5 \mu \mathrm{g} / \mathrm{mL})$ for $2 \mathrm{~h}$ to block AnxA2 function (B), treated with AnxA2 siRNA for $72 \mathrm{~h}$ to knock down the expression of AnxA2 (C), or transfected with a pEGFP-AnxA2 plasmid for $48 \mathrm{~h}$ to overexpress AnxA2 (D) prior to Clin-SA infection (MOI: 50). The adhesion and invasion assays were performed after incubation of MAC-T with bacteria for $1 \mathrm{~h}$. Dates are mean values \pm s.d. of three replicates. ${ }^{*} p<0.05$; ${ }^{* *} p<0.01$; ns: no significant difference. 
A
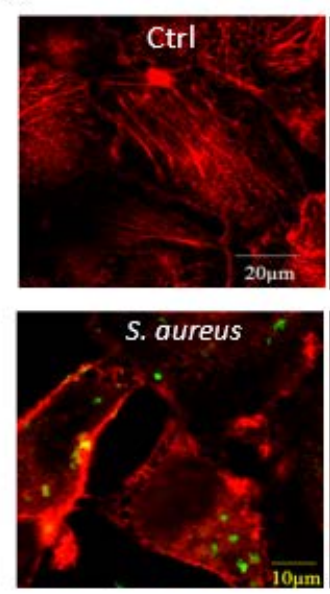
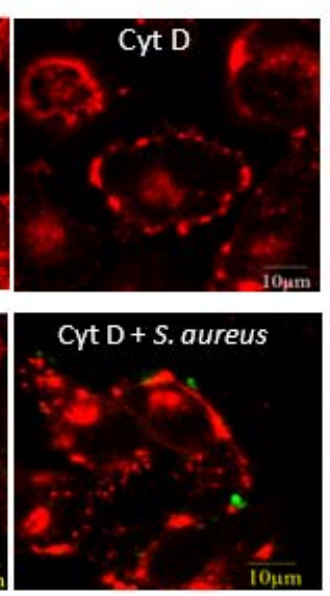

ATCC 25923

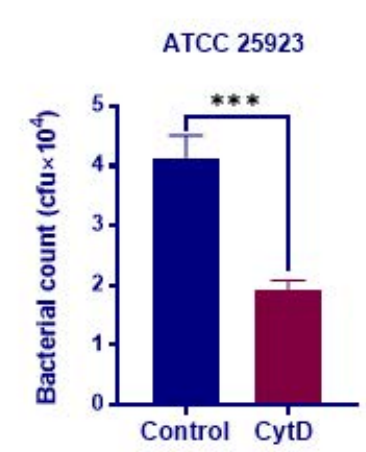

B
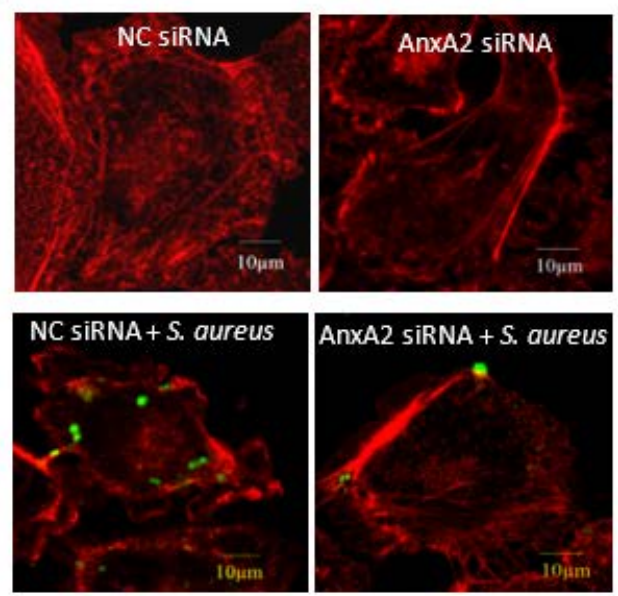

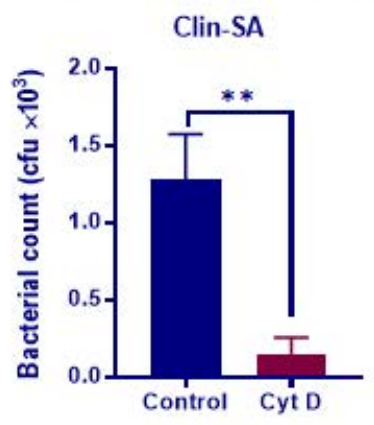

Figure 2. Engagement of AnxA2 in S. aureus-induced cytoskeleton reorganization. MAC-T cells were pre-treated with cytochalasin D (Cyt D) for $2 \mathrm{~h}$ (A-C) or AnxA2 siRNAfor $72 \mathrm{~h}$ (D), followed by infection with clinical isolate of $S$. aureus (Clin-SA, FITC-labeled) or S. aureus strain ATCC 25923 for $1 \mathrm{~h}$. F-actin was visualized by TRITC-conjugated phalloidin (A,D). Representative confocal microscopy images of cells infected with Clin-SA are shown (Green: S. aureus; Red: F-actin). Invasion of Clin-SA (B) as well as ATCC 25923 (C) was determined by gentamicin protection assay. The graph shows mean values \pm s.d. of three replicates. Each assay was repeated at least three times. ${ }^{* *} p<0.01$ and ${ }^{* * *} p<0.001$.

\subsection{Bacterial Engagement of AnxA2 Activates ILK/p38 MAPK Pathway}

We next sought to determine the downstream signal molecules involved in AnxA2mediated S. aureus invasion. We focused on ILK, which is essential for S. aureus internalization [37,38], and p38 mitogen-activated protein kinase (MAPK), a member of MAPK family that plays a role in regulating F-actin reorganization [39]. As expected, depletion of ILK with siRNA (Figure 3A) or inhibition of p38 MAPK activity (Figure 3B) interfered with $S$. aureus invasion into MAC-T cells. To verify whether AnxA2 engagement leads to upregulation in ILK and p38 MAPK activation, the expression of AnxA2 in MAC-T was knocked down before $S$. aureus infection. Western blot analysis showed that $S$. aureus infection increased the levels of ILK protein as well as p38 MAPK phosphorylation in a time-dependent manner in cells treated with negative control (NC) siRNA (Figure 3C). On the contrary, loss of AnxA2 significantly reduced the ILK response to S. aureus, and dramatically blocked S. aureus-induced p38 MAPK phosphorylation (Figure 3C), indicating that both ILK and p38 MAPK act downstream of AnxA2. Signaling from ILK has been shown to activate p38 MAPK $[40,41]$. Using ILK-deficient MAC-T cells, we confirmed that ILK is critical for S. aureus-induced p38 MAPK phosphorylation (Figure 3D). Taken together, our results suggest that ILK/p38 signaling pathway drives the AnxA2-mediated invasion of staphylococci. 


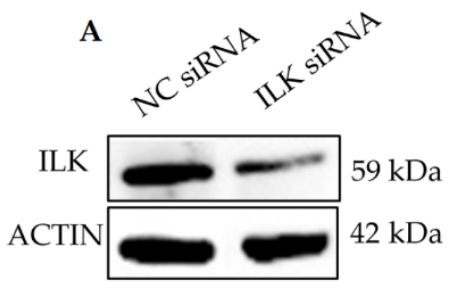

B
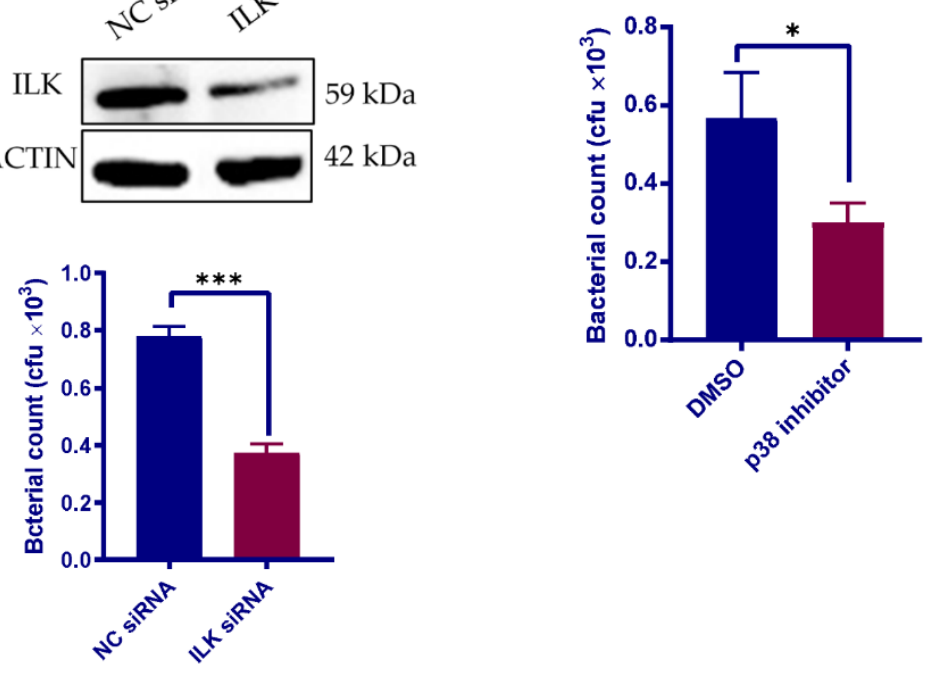

C

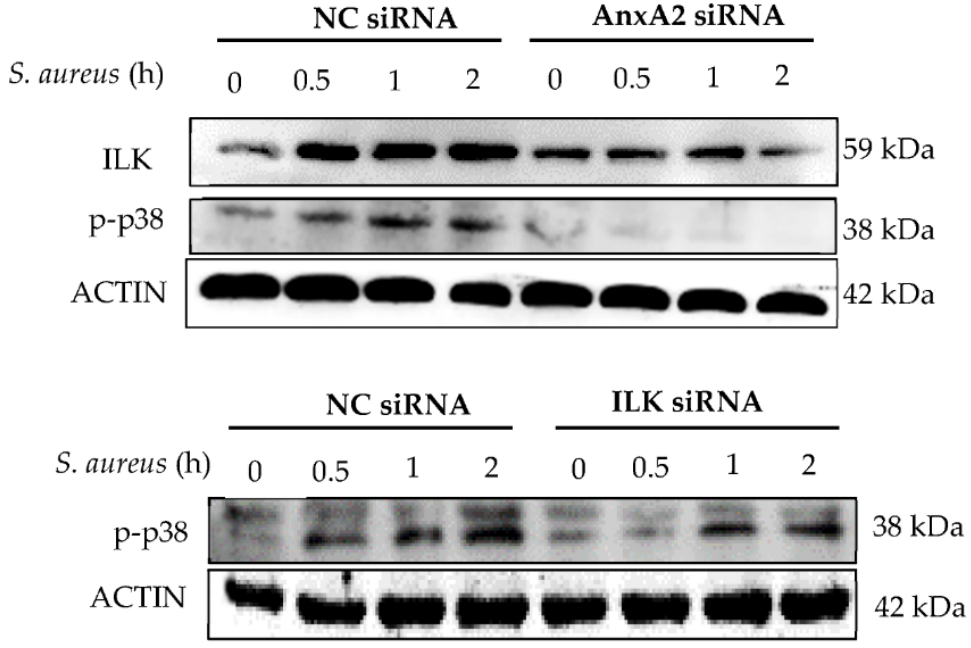

Figure 3. AnxA2 engagement activates ILK/p38 MAPK pathway. (A) Evaluation of the effect of ILK on S. aureus internalization by MAC-T. MAC-T cells were treated with either NC siRNA or ILK siRNA for $72 \mathrm{~h}$. Whole-cell extracts were analyzed by immunoblotting with anti-ILK (upper panel). $\beta$-actin is shown as a loading control. The ILK-deficient cells were then co-cultured with clinical isolate of $S$. aureus (Clin-SA) at an MOI of 50 for $1 \mathrm{~h}$. Bacterial invasion was determined by gentamicin protection assays (lower panel). The graph shows mean values \pm s.d. of three replicates. (B) Evaluation of the effect of p38 MAPK on S. aureus internalization by MAC-T. MAC-T cells were pre-treated with SB203580, a selective inhibitor of p38 MAPK, at $10 \mu \mathrm{M}$ for $2 \mathrm{~h}$ and infected with Clin-SA at an MOI of 50 for $1 \mathrm{~h}$. Bacterial invasion was determined by gentamicin protection assays. The graph shows mean values \pm s.d. of three replicates. (C) Evaluation of the effect of AnxA2 engagement on ILK expression and p38 MAPK phosphorylation. MAC-T cells were treated with either NC siRNA or AnxA2 siRNA for $72 \mathrm{~h}$ and then subjected to Clin-SA infection at a MOI of 25 for $2 \mathrm{~h}$. Whole-cell extracts were analyzed by immunoblotting with antibodies against AnxA2, ILK and phosphorylated p38 MAPK. $\beta$-actin is shown as a loading control. (D) Evaluation of the effect of ILK engagement on p38 MAPK phosphorylation. MAC-T cells were treated with siRNA and Clin-SA as described in (A). Whole-cell extracts were analyzed by immunoblotting with antibodies against ILK and phosphorylated p38 MAPK. $\beta$-actin is shown as a loading control. ${ }^{*} p<0.05$; ${ }^{* * *} p<0.001$.

\subsection{AnxA2 Is a Binding Partner of S. aureus ClfB}

Having established the importance of host AnxA2 in S. aureus invasion, we next sought to determine its interacting proteins in bacteria. Because only a limited number 
of bacteria were internalized by MAC-T cells, we were restricted in our studies to use the whole lysates of $S$. aureus-infected MAC-T to determine the AnxA2 interactors from intracellular bacteria by using co-IP assay. In order to mimic in vivo condition, the lysates from MAC-T cells were incubated with S. aureus extracts. The AnxA2-binding complex was then captured by Protein A/G Beads conjugated with anti-AnxA2 mAb. The presence of AnxA2 in the protein complex was confirmed by silver stain (data not shown) and Western blot analysis (Figure 4A) after the immunoprecipitated proteins were separated by SDS-PAGE. Using LC-MS/MS analysis, we identified 299 known entries of S. aureus in the immunoprecipitates. Among these, S. aureus ClfB was identified as a candidate of AnxA2-binding protein (Table S1). Fragment spectrum of a peptide derived from ClfB (G0XY85_STAAU) is shown in Figure 4B. The sequence recognized by AnxA2 is located at the N-terminal ligand binding A region of ClfB (Figure 4C). Notably, ClfA was not included in the bound proteins of AnxA2 (Table S1). In order to confirm the physical interaction of ClfB and AnxA2, a pull-down assay was performed by using GST-fused ClfB as bait protein. Because the genome of the Clin-SA was not sequenced in this work, we therefore amplified ClfB gene from ATCC 25923 to produce recombinant ClfB protein. Western blot analysis demonstrated the presence of AnxA2 in the protein complexes obtained from the GST pull-down assay (Figure 5).
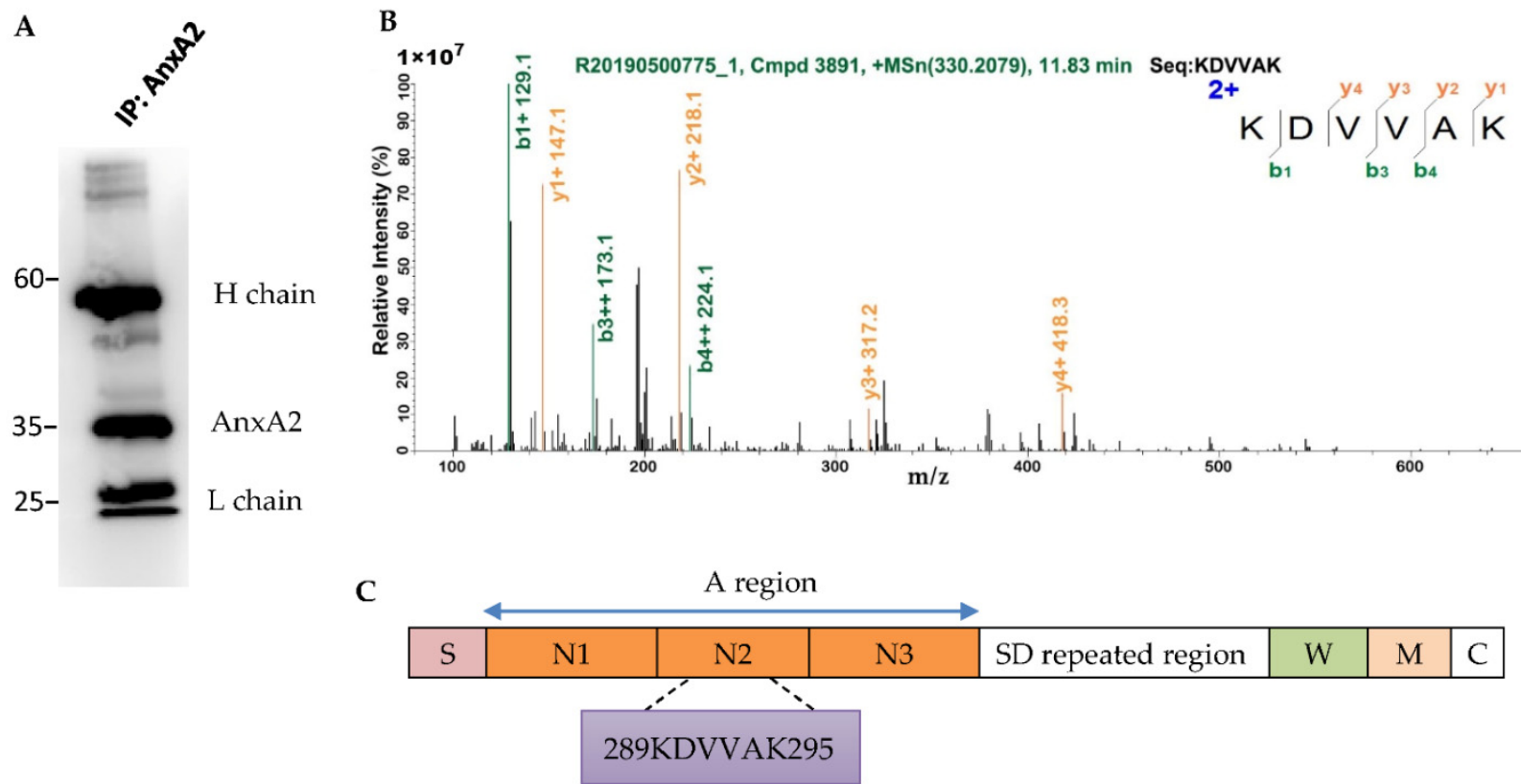

Figure 4. Identification of $S$. aureus $\mathrm{ClfB}$ as a binding partner of AnxA2. (A) AnxA2 detected by Western blot. Whole lysates from MAC-T cells were incubated overnight at $4{ }^{\circ} \mathrm{C}$ with the extracts from clinical isolate of S. aureus (Clin-SA) grown to early exponential phase. The protein A/G magnetic beads conjugated with anti-AnxA2 mAb were used to capture AnxA2-binding complex. Thereafter, protein complexes were separated on 12\% SDS-PAGE and subjected to Western blot analysis. IP, immunoprecipitation; H chain, IgG heavy chain; L chain, IgG light chain. (B) Data analysis of the MS/MS spectrum led to identification of a peptide with the sequence KDVVAK, which was part of ClfB protein. b- and y-ions are labelled. (C) Schematic diagram of ClfB structure indicating the signal sequences (S), the N-terminal ligand binding A region with three subdomains, N1, N2, and N3, the Ser-Asp dipepide (SD) repeated region, the wall-spanning regions $(\mathrm{W})$, the membrane-spanning regions $(\mathrm{M})$, and the charged C-terminal tail (C). The location of peptide sequence of ClfB recognized by AnxA2 is also shown. 
A

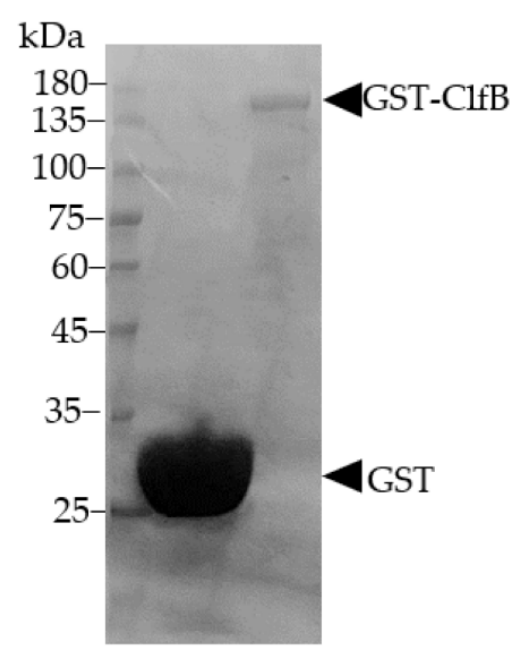

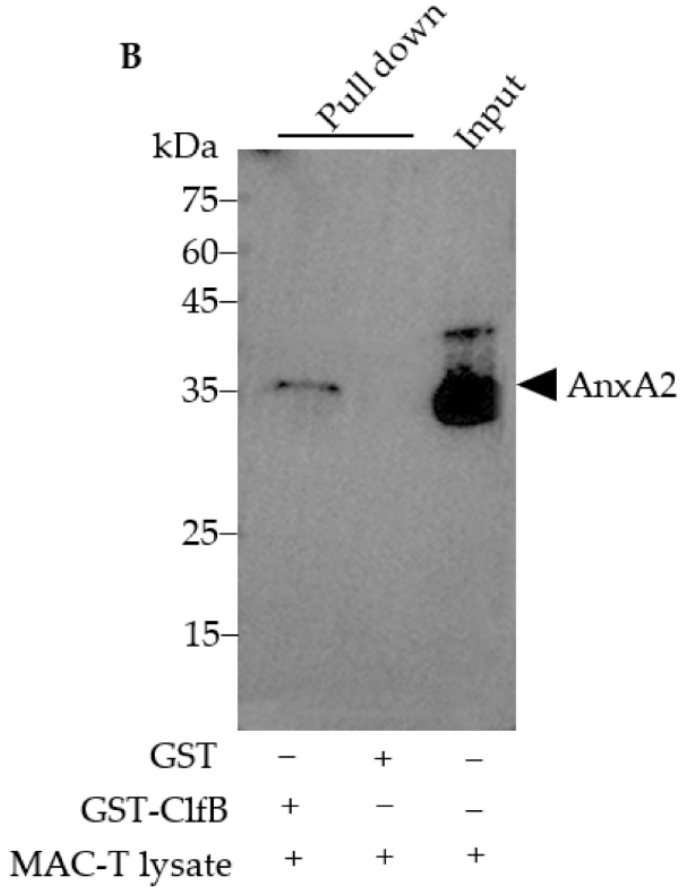

WB: anti-AnxA2

Figure 5. Binding of S. aureus ClfB to AnxA2 of MAC-T. (A) GST and GST-tagged recombinant ClfB produced from E. coli BL21 were purified and assessed by SDS-PAGE, and the proteins were visualized by Coomassie brilliant blue staining. (B) GST-ClfB protein and GST protein were combined to Sepharose CL-6B beads, and incubated with whole cell lysates prepared from MAC-T. The protein complexes were released by boiling, electrophoresed on 12\% SDS-PAGE, and subjected to Western blot analysis with anti-AnxA2 antibody.

\subsection{Interaction of ClfB and AnxA2 Regulates the Internalization of S. aureus}

The importance of AnxA2 binding by $\mathrm{ClfB}$ for $S$. aureus invasion was evaluated. We first incubated MAC-T cells with a recombinant ClfB protein prior to S. aureus ATCC 25923 infection. If ClfB merely severs as an adhesion molecule mediating the attachment of S. aureus to host cells, one could expect a reduction in S. aureus invasion when ClfB's ligands on host cells are occupied by recombinant ClfB protein. In sharp contrast to our expectation, gentamicin protection assays showed that pre-treatment with ClfB protein increased S. aureus uptake by MAC-T cells in a dose-dependent manner (Figure 6A), suggesting that $\mathrm{ClfB}$ plays a more significant role in bacterial invasion than in adherence. Since we have determined an interaction of AnxA2 and ClfB in our protein-protein binding assays, we next asked whether ClfB-mediated S. aureus internalization is dependent on AnxA2. To this end, we incubated the cells with an anti-AnxA2 antibody for $2 \mathrm{~h}$ before the addition of recombinant $\mathrm{ClfB}$ protein. As expected, pretreatment with anti-AnxA2 blocked the effect of recombinant ClfB protein on ATCC 25923 invasion into MAC-T cells, while no significant effect of the negative control IgG (human IgG) on S. aureus ATCC 25923 invasion was observed (Figure 6B). Similar results were obtained when using Clin-SA strain for infection (Figure 6C). In order to test if this response is specific to bovine mammary epithelial cells, we also used porcine intestinal epithelial cell line (IPEC-J2) for experiments. In line with the findings on MAC-T, pretreatment of anti-AnxA2 also blocked ClfB-stimulated increase in S. aureus invasion into IPEC-J2 (Figure 6D). Taken together, our results indicate that interaction of $\mathrm{ClfB}$ and AnxA2 is required for $S$. aureus invasion. 
A

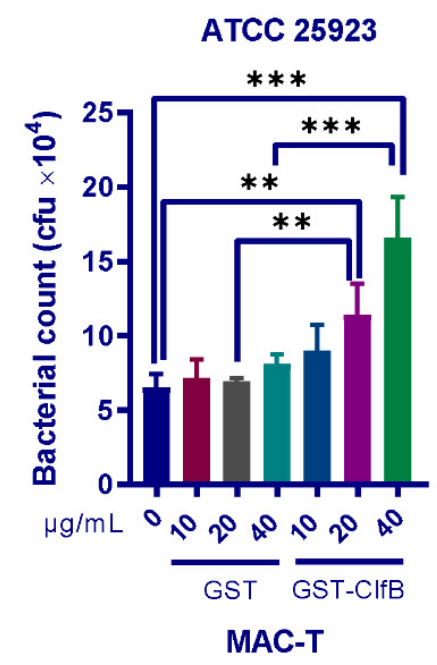

C

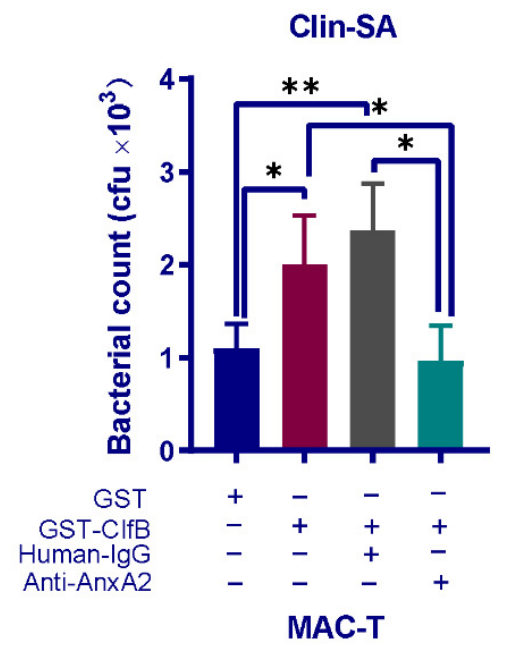

B

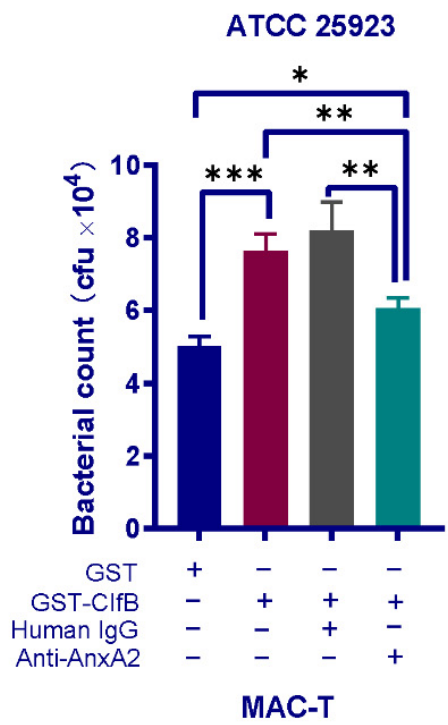

D

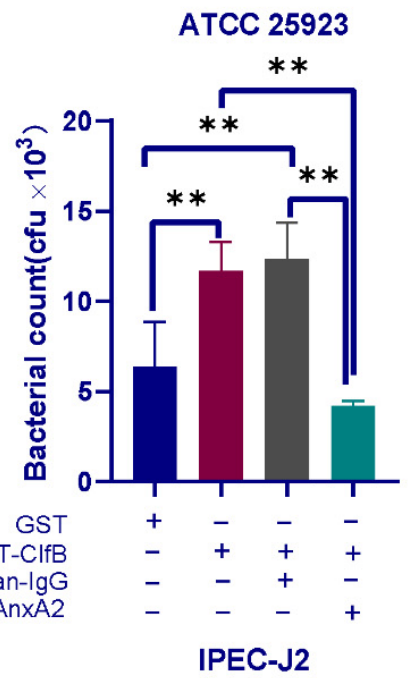

Figure 6. Interaction of $\mathrm{ClfB}$ and $\mathrm{AnxA2}$ is required for S. aureus invasion. (A) Recombinant $\mathrm{ClfB}$ enhances S. aureus invasion in a dose-dependent manner. MAC-T cells in 24-well plates were pretreated with recombinant or GST-tagged ClfB $(0-40 \mu \mathrm{g} / \mathrm{mL})$ for $1 \mathrm{~h}$, followed by co-incubation with S. aureus ATCC 25923 at an MOI of 25 for another $1 \mathrm{~h}$. (B-D) Anti-AnxA2 blocks recombinant ClfB -induced S. aureus internalization. MAC-T (B and C) or IPEC-J2 (D) were treated with antiAnxA2 antibody $(17.5 \mu \mathrm{g} / \mathrm{mL})$ or human IgG $(17.5 \mu \mathrm{g} / \mathrm{mL})$ for $2 \mathrm{~h}$ prior to exposure to GST-tagged recombinant ClfB $(20 \mu \mathrm{g} / \mathrm{mL})$ for $1 \mathrm{~h}$. After washing in DPBS 3 times, cells were co-cultured with S. aureus ATCC 25923 (B and D) at an MOI of 25 or clinical isolate of S. aureus (Clin-SA) (C) at an MOI of 50 for $1 \mathrm{~h}$. Cells treated with recombinant GST $(20 \mu \mathrm{g} / \mathrm{mL})$ or GST-tagged recombinant $\mathrm{ClfB}(20 \mu \mathrm{g} / \mathrm{mL})$ alone were served as controls. Bacterial invasion was determined by gentamicin protection assays. The graph shows mean values \pm s.d. of three replicates. ${ }^{*} p<0.05 ;{ }^{* *} p<0.01$; and *** $p<0.001$.

\section{Discussion}

In the present study, we demonstrate that AnxA2 is critical for S. aureus internalization into bovine mammary epithelial cells, and that ILK/p38 MAPK signal pathway is involved in this process. In addition, we identified S. aureus ClfB as a binding partner of AnxA2. Our results show that the interaction of AnxA2 and ClfB is necessary for S. aureus internalization. 
Although both host AnxA2 [31] and S. aureus ClfB [42] have been implicated in S. aureus infection, ours is the first to reveal a direct interaction of AnxA2 and ClfB.

AnxA2 has been shown to mediate the uptake of a wide range of bacterial species by nonprofessional phagocytic cells, for example Pseudomonas aeruginosa [30], Salmonella typhimurium [43], and Mycoplasma pneumoniae [29]. Early studies suggest that AnxA2 assists S. aureus adhesion [31]. Our observations, however, suggested that AnxA2 engagement induced bacterial invasion rather than adherence. The uptake of bacterial pathogens by non-professional phagocytic cells requires not only interaction with cell surface proteins but also subversion of actin cytoskeletal dynamics. AnxA2 is well known for its F-actin binding and bundling activity in the dynamic remolding of the actin cytoskeleton [44-48]. Thus, the underlying mechanism by which AnxA2 triggers invasion appears to be associated with its ability to regulate actin cytoskeleton. Supporting this hypothesis, we observed that AnxA2 depletion prevented S. aureus invasion, concomitant with disruption of F-actin reorganization.

The signaling pathways downstream of AnxA2 during S. aureus invasion remain largely unknown. By using AnxA2-deficient MAC-T cells, we demonstrated that AnxA2 engagement is required for $S$. aureus-stimulated upregulation in ILK, a serine-threonine protein kinase that binds the cytoplasmic domains of $\beta 1$ and $\beta 3$ integrin subunits to regulate integrin-actin connection and acts as the immediate downstream effector of integrin signal transduction [49,50]. Given that integrin $\alpha 5 \beta 1$ promotes bacterial adhesion and triggers uptake process [35], our results allow us to argue that there exists a functional link between AnxA2 and integrin $\alpha 5 \beta 1$ during S. aureus internalization. Indeed, AnxA2 has been shown to activate integrin $\alpha 5 \beta 1$ via direct protein-protein interaction between AnxA2 and integrin $\alpha 5$ cytoplasmic domain [51]. In another study, AnxA2 has been shown to mediate the internalization of cell surface integrin $\beta 1$ [52]. However, further investigation is required to evaluate the potential associations between AnxA2 and integrins during S. aureus infection. We have also identified $\mathrm{p} 38$ MAPK as a downstream effector of ILK, in line with previous studies demonstrating that ILK regulates actin cytoskeleton remodeling via p38 MAPK phosphorylation [53]. Taken together, our results suggest that AnxA2 couples to ILK/p38 MAPK pathway for modulating S. aureus invasion.

S. aureus expresses various surface proteins that mediate the adhesion and invasion of the pathogen into host cells by binding to different host molecules. We next carried out in vitro protein-binding assays to identify the AnxA2 binding proteins on the bacteria. One of our objectives is to confirm the interaction of ClfA and AnxA2, which has been previously reported by Ashraf et al. [33]. Surprisingly, ClfA protein was not detectable in the AnxA2-precipitated proteins. Indeed, our work identified AnxA2 as the ligand recognized by ClfB. It should be noted that, in the study of Ashraf et al. [33], a recombinant ClfA protein was used as a bait to pull down lysates of bovine mammary epithelial cells. By this means, ClfB was not included in the in vitro binding system. In contrast, in the present study, we designed a protein-protein binding assay to determine the interactors of AnxA2 in bacteria lysates, which enabled both ClfA and ClfB proteins to be exposed to AnxA2 simultaneously. It is also noteworthy that we used bacteria in the early exponential phase of growth for our in vitro binding assay. Early studies have shown that ClfA protein is expressed throughout bacterial growth, whereas ClfB is only expressed in the early exponential phase of growth $[54,55]$. Therefore, our finding that AnxA2 binding to ClfB rather than ClfA raises a possibility that $\mathrm{ClfB}$ has higher binding ability to AnxA2 than $\mathrm{ClfA}$, or the expression of $\mathrm{ClfB}$ is higher than ClfA in early exponential phase, or both. Nevertheless, our work does not exclude the possibility that ClfA could bind to AnxA2 when cells lose ClfB expression in late exponential or stationary phase.

ClfB has been previously shown to promote the adherence of $S$. aureus to host cells $[42,54]$. Based on these findings, we hypothesized that pre-occupation of ClfB ligands on MAC$\mathrm{T}$ using recombinant ClfB protein could lead to reduced S. aureus adherence, resulting in decreased bacterial internalization. However, counter to our initial prediction, we found that pre-treatment with recombinant ClfB protein enhanced subsequent $S$. aureus 
uptake by MAC-T in a dose-dependent manner. The result thus allows us to argue that ClfB functions to drive $S$. aureus internalization rather than adherence. In addition, we found that recombinant $\mathrm{ClfB}$ protein-induced $S$. aureus uptake by MAC-T and IPEC-J2 was specially blocked by anti-AnxA2 antibody, suggesting that binding of ClfB to AnxA2 is required for staphylococcal invasion into host cells.

The significance of ClfB in the context of S. aureus mastitis remains unclear. Notably, although both ClfB and ClfA have been implicated in the pathogenesis of S. aureus in various animal models [42,56-59], their contributions appear to be distinct, considering the fact that immunization with ClfA only provides modest protection [60] whereas vaccination with $\mathrm{ClfB}$ confers significant protection against $S$. aureus infection [56]. In addition, the frequency of $C l f B$ gene was found to be higher than that of $C l f A$ in $S$.aureus isolates for humans [61] and dairy cattle [62]. Additional research is thus warranted to define the relative contributions of these two proteins to the development of S. aureus mastitis in bovine.

\section{Conclusions}

In summary, the present study reveals a novel, previously unidentified role for ClfBAnxA2 binding in $S$. aureus invasion. We also defined a signal transduction pathway downstream of AnxA2, which involves the upregulation of ILK and subsequent activation of p38 MAPK. We show for the first time that binding of ClfB to AnxA2 plays a role during $S$. aureus invasion into MAC-T. It is suggested that targeting the association between ClfB and AnxA2 might confer protection against $S$. aureus mastitis in dairy cattle.

Supplementary Materials: The following are available online at https:/ / www.mdpi.com/article/10 .3390/microorganisms9102090/s1, Table S1: Peptides identified by LC-MS/MS analysis of AnxA2precipitated S. aureus proteins.

Author Contributions: Conceptualization, X.T.; Methodology, Y.-T.Y. and X.T.; Formal Analysis, Y.-T.Y. and W.-J.R.; Data Curation, J.Y. and R.L.; Validation, W.-J.R. and J.Y.; Writing Original Draft Preparation, Y.-T.Y.; Writing Review and Editing, Supervision, X.T. and A.-F.D.; Funding Acquisition, X.T. All authors have read and agreed to the published version of the manuscript.

Funding: This study was funded by the Key R\&D Program of Zhejiang Province (Project No. 2020C02032) and the National Key R\&D Program of China (Project No. 2017YFD0502200).

Institutional Review Board Statement: Not applicable.

Informed Consent Statement: Not applicable.

Data Availability Statement: All data analyzed during this study are included in this published article and its supplementary information flies.

Acknowledgments: We wish to thank Zhu YH for the MAC-T cells. The LC-MS/MS analysis was performed by Shanghai Applied Protein Technology Co. Ltd., China.

Conflicts of Interest: The authors declare that they have no conflict of interest.

\section{References}

1. Lowy, F.D. Staphylococcus aureus infections. N. Engl. J. Med. 1998, 339, 520-532. [CrossRef] [PubMed]

2. Dufour, S.; Dohoo, I.; Barkema, H.; Descôteaux, L.; Devries, T.; Reyher, K.; Roy, J.-P.; Scholl, D. Manageable risk factors associated with the lactational incidence, elimination, and prevalence of Staphylococcus aureus intramammary infections in dairy cows. $J$. Dairy Sci. 2012, 95, 1283-1300. [CrossRef]

3. Cvetnić, L.; Samardžija, M.; Duvnjak, S.; Habrun, B.; Cvetnić, M.; Tkalec, V.J.; Đuričić, D.; Benić, M. Multi locus sequence typing and spa typing of Staphylococcus aureus isolated from the milk of cows with subclinical mastitis in Croatia. Microorganisms 2021, 9, 725. [CrossRef]

4. Burović, J. Isolation of bovine clinical mastitis bacterial pathogens and their antimicrobial susceptibility in the Zenica region in 2017. Vet. Stanica. 2020, 51, 47-52. [CrossRef]

5. Benić, M.; Maćešić, N.; Cvetnić, L.; Habrun, B.; Cvetnić, Z.; Turk, R.; Duričić, D.; Lojkić, M.; Dobranić, V.; Valpotić, H.; et al. Bovine mastitis: A persistent and evolving problem requiring novel approaches for its control—A review. Vet. Arhiv. 2018, 88, 535-557. [CrossRef] 
6. Rainard, P.; Foucras, G.; Fitzgerald, J.R.; Watts, J.L.; Koop, G.; Middleton, J.R. Knowledge gaps and research priorities in Staphylococcus aureus mastitis control. Transbound. Emerg. Dis. 2018, 65, 149-165. [CrossRef]

7. Algharib, S.; Dawood, A.; Xie, S. Nanoparticles for treatment of bovine Staphylococcus aureus mastitis. Drug Deliv. 2020, 27, 292-308. [CrossRef] [PubMed]

8. Grispoldi, L.; Massetti, L.; Sechi, P.; Iulietto, M.F.; Ceccarelli, M.; Karama, M.; Popescu, P.A.; Pandolfi, F.; Cenci-Goga, B. Short communication: Characterization of enterotoxin-producing Staphylococcus aureus isolated from mastitic cows. J. Dairy Sci. 2019, 102, 1059-1065. [CrossRef] [PubMed]

9. Dai, J.; Wu, S.; Huang, J.; Wu, Q.; Zhang, F.; Zhang, J.; Wang, J.; Ding, Y.; Zhang, S.; Yang, X.; et al. Prevalence and characterization of Staphylococcus aureus isolated from pasteurized milk in china. Front. Microbiol. 2019, 10, 641. [CrossRef] [PubMed]

10. Richardson, E.J.; Bacigalupe, R.; Harrison, E.; Weinert, L.A.; Lycett, S.; Vrieling, M.; Robb, K.; Hoskisson, P.A.; Holden, M.T.G.; Feil, E.J.; et al. Gene exchange drives the ecological success of a multi-host bacterial pathogen. Nat. Ecol. Evol. 2018, 2, 1468-1478. [CrossRef] [PubMed]

11. Spoor, L.E.; McAdam, P.R.; Weinert, L.A.; Rambaut, A.; Hasman, H.; Aarestrup, F.; Kearns, A.M.; Larsen, A.R.; Skov, R.L.; Fitzgerald, J.R. Livestock origin for a human pandemic clone of community-associated methicillin-resistant Staphylococcus aureus. mBio 2013, 4, e00356-13. [CrossRef]

12. Menzies, B.E.; Kourteva, I. Internalization of Staphylococcus aureus by endothelial cells induces apoptosis. Infect. Immun. 1998, 66, 5994-5998. [CrossRef] [PubMed]

13. Bayles, K.W.; Wesson, C.A.; Liou, L.E.; Fox, L.K.; Bohach, G.A.; Trumble, W.R. Intracellular Staphylococcus aureus escapes the endosome and induces apoptosis in epithelial cells. Infect. Immun. 1998, 66, 336-342. [CrossRef] [PubMed]

14. Stelzner, K.; Winkler, A.-C.; Liang, C.; Boyny, A.; Ade, C.P.; Dandekar, T.; Fraunholz, M.J.; Rudel, T. Intracellular Staphylococcus aureus perturbs the host cell $\mathrm{Ca}^{2+}$ homeostasis to promote cell death. mBio 2020, 11, e02250-20. [CrossRef]

15. Edwards, A.M.; Potter, U.; Meenan, N.A.G.; Potts, J.R.; Massey, R.C. Staphylococcus aureus keratinocyte invasion is dependent upon multiple high-affinity fibronectin-binding repeats within FnBPA. PLoS ONE 2011, 6, e18899. [CrossRef] [PubMed]

16. Brouillette, E.; Grondin, G.; Shkreta, L.; Lacasse, P.; Talbot, B.G. In vivo and in vitro demonstration that Staphylococcus aureus is an intracellular pathogen in the presence or absence of fibronectin-binding proteins. Microb. Pathog. 2003, 35, 159-168. [CrossRef]

17. Bouchard, D.S.; Rault, L.; Berkova, N.; Le Loir, Y.; Even, S. Inhibition of Staphylococcus aureus invasion into bovine mammary epithelial cells by contact with live Lactobacillus casei. Appl. Environ. Microbiol. 2013, 79, 877-885. [CrossRef]

18. Almeida, R.A.; Matthews, K.R.; Cifrian, E.; Guidry, A.J.; Oliver, S.P. Staphylococcus aureus invasion of bovine mammary epithelial cells. J. Dairy Sci. 1996, 79, 1021-1026. [CrossRef]

19. Al Kindi, A.; Alkahtani, A.M.; Nalubega, M.; El-Chami, C.; O’Neill, C.; Arkwright, P.D.; Pennock, J.L. Staphylococcus aureus internalized by skin keratinocytes evade antibiotic killing. Front. Microbiol. 2019, 10, 2242. [CrossRef]

20. Fraunholz, M.; Sinha, B. Intracellular Staphylococcus aureus: Live-in and let die. Front. Cell. Infect. Microbiol. 2012, 2, 43. [CrossRef]

21. Peyrusson, F.; Varet, H.; Nguyen, T.K.; Legendre, R.; Sismeiro, O.; Coppée, J.-Y.; Wolz, C.; Tenson, T.; Van Bambeke, F. Intracellular Staphylococcus aureus persisters upon antibiotic exposure. Nat. Commun. 2020, 11, 2200. [CrossRef] [PubMed]

22. Alva-Murillo, N.; López-Meza, J.E.; Ochoa-Zarzosa, A. Nonprofessional phagocytic cell receptors involved in Staphylococcus aureus internalization. BioMed Res. Int. 2014, 2014, 538546. [CrossRef] [PubMed]

23. Foster, T.J.; Geoghegan, J.A.; Ganesh, V.K.; Höök, M. Adhesion, invasion and evasion: The many functions of the surface proteins of Staphylococcus aureus. Nat. Rev. Genet. 2013, 12, 49-62. [CrossRef]

24. Geoghegan, J.A.; Foster, T.J. Cell Wall-anchored surface proteins of Staphylococcus aureus: Many proteins, multiple functions. Curr. Top. Microbiol. Immunol. 2015, 409, 95-120. [CrossRef]

25. Speziale, P.; Arciola, C.R.; Pietrocola, G. Fibronectin and its role in human infective diseases. Cells 2019, 8, 1516. [CrossRef]

26. Fowler, T.; Wann, E.R.; Joh, D.; Johansson, S.; Foster, T.J.; Hook, M. Cellular invasion by Staphylococcus aureus involves a fibronectin bridge between the bacterial fibronectin-binding MSCRAMMs and host cell beta1 integrins. Eur. J. Cell Biol. 2000, 79, 672-679. [CrossRef]

27. Agerer, F.; Lux, S.; Michel, A.; Rohde, M.; Ohlsen, K.; Hauck, C.R. Cellular invasion by Staphylococcus aureus reveals a functional link between focal adhesion kinase and cortactin in integrin-mediated internalisation. J. Cell Sci. 2005, 118, 2189-2200. [CrossRef] [PubMed]

28. Bur, S.; Preissner, K.T.; Herrmann, M.; Bischoff, M. The Staphylococcus aureus extracellular adherence protein promotes bacterial internalization by keratinocytes independent of fibronectin-binding proteins. J. Investig. Dermatol. 2013, 133, 2004-2012. [CrossRef] [PubMed]

29. Somarajan, S.R.; Al-Asadi, F.; Ramasamy, K.; Pandranki, L.; Baseman, J.B.; Kannan, T.R. Annexin A2 mediates Mycoplasma pneumoniae community-acquired respiratory distress syndrome toxin binding to eukaryotic cells. mBio 2014, 5, e01497-14. [CrossRef] [PubMed]

30. Kirschnek, S.; Adams, C.; Gulbins, E. Annexin II is a novel receptor for Pseudomonas aeruginosa. Biochem. Biophys. Res. Commun. 2005, 327, 900-906. [CrossRef]

31. He, X.; Zhang, W.; Chang, Q.; Su, Z.; Gong, D.; Zhou, Y.; Xiao, J.; Drelich, A.; Liu, Y.; Popov, V.; et al. A new role for host Annexin A2 in establishing bacterial adhesion to vascular endothelial cells: Lines of evidence from atomic force microscopy and an in vivo study. Lab. Investig. 2019, 99, 1650-1660. [CrossRef] [PubMed] 
32. Grindheim, A.K.; Saraste, J.; Vedeler, A. Protein phosphorylation and its role in the regulation of Annexin A2 function. Biochim. Biophys. Acta BBA Gen. Subj. 2017, 1861, 2515-2529. [CrossRef]

33. Ashraf, S.; Cheng, J.; Zhao, X. Clumping factor A of Staphylococcus aureus interacts with AnnexinA2 on mammary epithelial cells. Sci. Rep. 2017, 7, 40608. [CrossRef] [PubMed]

34. Tribelli, P.M.; Luqman, A.; Nguyen, M.; Madlung, J.; Fan, S.; Macek, B.; Sass, P.; Bitschar, K.; Schittek, B.; Kretschmer, D.; et al. Staphylococcus aureus $\mathrm{Lpl}$ protein triggers human host cell invasion via activation of Hsp90 receptor. Cell. Microbiol. 2019, 22, e13111. [CrossRef]

35. Sinha, B.; Francois, P.P.; Nusse, O.; Foti, M.; Hartford, O.M.; Vaudaux, P.; Foster, T.J.; Lew, D.P.; Herrmann, M.; Krause, K.H. Fibronectin-binding protein acts as Staphylococcus aureus invasin via fibronectin bridging to integrin $\alpha 5 \beta 1$. Cell. Microbiol. 1999, 1, 101-117. [CrossRef] [PubMed]

36. Hayes, M.J.; Shao, D.-M.; Grieve, A.; Levine, T.; Bailly, M.; Moss, S.E. Annexin A2 at the interface between F-actin and membranes enriched in phosphatidylinositol 4,5,-bisphosphate. Biochim. Biophys. Acta BBA Bioenerg. 2009, 1793, 1086-1095. [CrossRef] [PubMed]

37. Sayedyahossein, S.; Xu, S.X.; Rudkouskaya, A.; McGavin, M.J.; McCormick, J.K.; Dagnino, L. Staphylococcus aureus keratinocyte invasion is mediated by integrin-linked kinase and Rac1. FASEB J. 2014, 29, 711-723. [CrossRef] [PubMed]

38. Wang, B.; Yurecko, R.S.; Dedhar, S.; Cleary, P.P. Integrin-linked kinase is an essential link between integrins and uptake of bacterial pathogens by epithelial cells. Cell. Microbiol. 2005, 8, 257-266. [CrossRef]

39. Okada, T.; Otani, H.; Wu, Y.; Kyoi, S.; Enoki, C.; Fujiwara, H.; Sumida, T.; Hattori, R.; Imamura, H. Role of F-actin organization in p38 MAP kinase-mediated apoptosis and necrosis in neonatal rat cardiomyocytes subjected to simulated ischemia and reoxygenation. Am. J. Physiol. Circ. Physiol. 2005, 289, H2310-H2318. [CrossRef]

40. Smeeton, J.; Zhang, X.; Bulus, N.; Mernaugh, G.; Lange, A.; Karner, C.; Carroll, T.J.; Fässler, R.; Pozzi, A.; Rosenblum, N.D.; et al. Integrin-linked kinase regulates p38 MAPK-dependent cell cycle arrest in ureteric bud development. Development 2010, 137, 3233-3243. [CrossRef]

41. Yue, G.; Song, W.; Xu, S.; Sun, Y.; Wang, Z.-L. Role of ILK/p38 pathway in mediating the enhanced osteogenic differentiation of bone marrow mesenchymal stem cells on amorphous carbon coating. Biomater. Sci. 2018, 7, 975-984. [CrossRef]

42. O'Brien, L.M.; Walsh, E.J.; Massey, R.C.; Peacock, S.J.; Foster, T.J. Staphylococcus aureus clumping factor B (ClfB) promotes adherence to human type I cytokeratin 10: Implications for nasal colonization. Cell. Microbiol. 2002, 4, 759-770. [CrossRef]

43. Jolly, C.; Winfree, S.; Hansen, B.; Steele-Mortimer, O. The Annexin A2/p11 complex is required for efficient invasion of Salmonella typhimurium in epithelial cells. Cell. Microbiol. 2013, 16, 64-77. [CrossRef] [PubMed]

44. Thiel, C.; Osborn, M.; Gerke, V. The tight association of the tyrosine kinase substrate Annexin II with the submembranous cytoskeleton depends on intact p11- and Ca(2+)-binding sites. J. Cell Sci. 1992, 103, 733-742. [CrossRef] [PubMed]

45. Jones, P.; Moore, G.; Waisman, D. A nonapeptide to the putative F-actin binding site of Annexin-II tetramer inhibits its calciumdependent activation of actin filament bundling. J. Biol. Chem. 1992, 267, 13993-13997. [CrossRef]

46. Filipenko, N.R.; Waisman, D. The C terminus of Annexin II mediates binding to F-actin. J. Biol. Chem. 2001, 276, 5310-5315. [CrossRef]

47. Hayes, M.J.; Rescher, U.; Gerke, V.; Moss, S.E. Annexin-actin interactions. Traffic 2004, 5, 571-576. [CrossRef]

48. Grieve, A.G.; Moss, S.E.; Hayes, M.J. Annexin A2 at the interface of actin and membrane dynamics: A focus on its roles in endocytosis and cell polarization. Int. J. Cell Biol. 2012, 2012, 852430. [CrossRef]

49. Ghatak, S.; Morgner, J.; Wickström, S.A. ILK: A pseudokinase with a unique function in the integrin-actin linkage. Biochem. Soc. Trans. 2013, 41, 995-1001. [CrossRef]

50. Hannigan, G.E.; Mcdonald, P.C.; Walsh, M.P.; Dedhar, S. Integrin-linked kinase: Not so 'pseudo' after all. Oncogene 2011, 30, 4375-4385. [CrossRef]

51. Zhang, C.; Zhou, T.; Chen, Z.; Yan, M.; Li, B.; Lv, H.; Wang, C.; Xiang, S.; Shi, L.; Zhu, Y.; et al. Coupling of integrin $\alpha 5$ to Annexin A2 by flow drives endothelial activation. Circ. Res. 2020, 127, 1074-1090. [CrossRef]

52. Rankin, C.R.; Hilgarth, R.S.; Leoni, G.; Beste, K.D.; Kwon, M.; Parkos, C.A.; Nusrat, A. AnnexinA2 regulates $\beta 1$ integrin internalization and intestinal epithelial cell migration. FASEB J. 2012, 26, 56.6. [CrossRef]

53. Esfandiarei, M.; Yazdi, S.A.; Gray, V.; Dedhar, S.; Van Breemen, C. Integrin-linked kinase functions as a downstream signal of platelet-derived growth factor to regulate actin polymerization and vascular smooth muscle cell migration. BMC Cell Biol. 2010, 11, 16. [CrossRef]

54. Ni, E.D.; Perkins, S.; Francois, P.; Vaudaux, P.; Hook, M.; Foster, T.J. Clumping factor B (ClfB), a new surface-located fibrinogenbinding adhesin of Staphylococcus aureus. Mol. Microbiol. 1998, 30, 245-257.

55. Mcaleese, F.M.; Walsh, E.J.; Sieprawska, M.; Potempa, J.; Foster, T.J. Loss of clumping factor B fibrinogen binding activity by Staphylococcus aureus involves cessation of transcription, shedding and cleavage by metalloprotease. J. Biol. Chem. 2001, 276, 29969-29978. [CrossRef] [PubMed]

56. Lacey, K.A.; Mulcahy, M.E.; Towell, A.M.; Geoghegan, J.A.; McLoughlin, R.M. Clumping factor B is an important virulence factor during Staphylococcus aureus skin infection and a promising vaccine target. PLOS Pathog. 2019, 15, e1007713. [CrossRef]

57. Mulcahy, M.E.; Geoghegan, J.A.; Monk, I.; O'Keeffe, K.M.; Walsh, E.J.; Foster, T.J.; McLoughlin, R.M. Nasal colonisation by Staphylococcus aureus depends upon clumping factor B binding to the squamous epithelial cell envelope protein Loricrin. PLOS Pathog. 2012, 8, e1003092. [CrossRef] [PubMed] 
58. Herman-Bausier, P.; Labate, C.; Towell, A.M.; Derclaye, S.; Geoghegan, J.A.; Dufrene, Y.F. Staphylococcus aureus clumping factor A is a force-sensitive molecular switch that activates bacterial adhesion. Proc. Natl. Acad. Sci. USA 2018, 115, 5564-5569. [CrossRef]

59. Kwiecinski, J.; Jin, T.; Josefsson, E. Surface proteins of Staphylococcus aureus play an important role in experimental skin infection. APMIS 2014, 122, 1240-1250. [CrossRef]

60. Li, X.; Wang, X.; Thompson, C.D.; Park, S.; Park, W.B.; Lee, J.C. Preclinical efficacy of clumping factor A in prevention of Staphylococcus aureus infection. mBio 2016, 7, e02232-15. [CrossRef]

61. Soltani, E.; Farrokhi, E.; Zamanzad, B.; Abadi, M.S.S.; Deris, F.; Soltani, A.; Gholipour, A. Prevalence and distribution of adhesins and the expression of fibronectin-binding protein (FnbA and FnbB) among Staphylococcus aureus isolates from Shahrekord Hospitals. BMC Res. Notes 2019, 12, 49. [CrossRef] [PubMed]

62. Sharma, V.; Sharma, S.; Dahiya, D.K.; Khan, A.; Mathur, M.; Sharma, A. Coagulase gene polymorphism, enterotoxigenecity, biofilm production, and antibiotic resistance in Staphylococcus aureus isolated from bovine raw milk in North West India. Ann. Clin. Microbiol. Antimicrob. 2017, 16, 65. [CrossRef] [PubMed] 